\title{
SHORT COMMENTARY
}

\section{Effect of Hydroxyurea on Priapism in Men with Sickle Cell Disease}

\author{
BF Morrison ${ }^{1}$, P Hamilton ${ }^{1}$, M Reid ${ }^{2}$
}

\begin{abstract}
Priapism is a devastating complication of sickle cell disease (SCD) with no uniformly accepted prophylaxis. Hydroxyurea (HU) has shown benefit in preventing chronic complications of SCD. We sought to determine the association between HU therapy and the prevention of priapism episodes in men with SCD. A retrospective case series study was conducted between July 1 and September 30, 2014, recruiting men treated at the Sickle Cell Unit, The University of the West Indies, Mona, Jamaica, who had a history of priapism and exposure to HU therapy. A questionnaire on priapism was administered, and changes in the characteristics of priapism episodes relative to HU therapy were recorded. Ten men with a mean age of $26.2 \pm 10.7$ years consented for the study. The most frequent indication for $H U$ use was prevention of recurrent painful crises (50\%). Three patients had baseline priapism episodes occurring daily or on alternate days. The baseline duration of the priapism episodes was greater than two hours in $50 \%$ of those interviewed, with 30\% lasting over five hours. Five (50\%) of the patients had cessation of episodes while on HU. Of the patients who continued to have priapism while on HU therapy, four had episodes lasting less than one hour, with one patient having episodes lasting beyond five hours. Chronic HU therapy appeared to be associated with an amelioration of recurrent priapism episodes in men with SCD.
\end{abstract}

Keywords: Hydroxyurea, priapism, sickle cell, stuttering priapism

\section{Efecto de la hidroxiurea en el priapismo en los hombres con enfermedad de células falciformes}

BF Morrison ${ }^{1}$, P Hamilton $^{1}$, M Reid ${ }^{2}$

\begin{abstract}
RESUMEN
El priapismo es una complicación devastadora de la enfermedad de células falciformes (ECF) sin ninguna profilaxis uniformemente aceptada. La hidroxiurea (HU) ha mostrado beneficios en la prevención de complicaciones crónicas de la ECF. Buscamos determinar la asociación de la terapia de HU en hombres con ECF en la prevención de episodios de priapismo. Se llevó a cabo un estudio retrospectivo de serie de casos, entre 1 de julio y 30 de septiembre de 2014, para lo cual se reclutaron hombres bajo tratamiento en la Unidad de Sicklemia de la Universidad de West Indies, Mona, Jamaica, que tenían una historia de priapismo y exposición a la terapia de HU. Se aplicó un cuestionario sobre el priapismo, y se registraron cambios en las características de los episodios de priapismo en relación con la terapia de HU. Diez hombres
\end{abstract}

From: 'Department of Surgery, The University of the West Indies, Mona, Jamaica, West Indies and ${ }^{2}$ Tropical Metabolism Research Institute, The University of the West Indies, Mona, Jamaica, West Indies.
Correspondence: Dr B Morrison, Department of Surgery, Faculty of Medical Sciences, The University of the West Indies, Mona, Kingston 7, Jamaica, West Indies. Email: belinda.morrison02@ uwimona.edu.jm 
de $26.2 \pm 10.7$ edad promedio dieron su consentimiento para el estudio. La indicación más frecuente para el uso de HU fue la prevención de crisis dolorosas recurrentes (50\%). Tres pacientes tuvieron episodios de priapismo basal que ocurrían todos los días o en días alternos. La duración inicial de los episodios de priapismo fue más de dos horas en el 50\% de los entrevistados, con un 30\% con una duración de más de cinco horas. Cinco (50\%) de los pacientes tuvieron clausura de los episodios bajo el tratamiento con HU. De los pacientes que seguían teniendo priapismo mientras se hallaban bajo terapia de HU, cuatro tuvieron episodios de menos de una hora, y uno tuvo episodios de más de cinco horas. La terapia crónica de HU pareció estar asociada con un mejoramiento de los episodios recurrentes de priapismo en hombres con ECF.

Palabras clave: Hidroxiurea, priapismo, células falciformes, priapismo

West Indian Med J 2017; 66 (4): 519

\section{INTRODUCTION}

Hydroxyurea (HU) is a disease-modifying agent in the management of sickle cell disease (SCD). Chronic HU therapy has shown sustained benefit in reversing or preventing chronic organ injury in SCD. Hydroxyurea reduces the rates of vaso-occlusive painful crises and acute chest syndrome and improves survival (1-3). Hydroxyurea, which is a nitric oxide (NO) donor, is thought to act prophylactically in priapism by increasing bioavailable NO levels (4). The drug has a unique advantage of being relatively inexpensive, requires only once daily dosing and is orally administered.

Priapism is a devastating complication of SCD typified by recurrent, prolonged, painful episodes of penile erection (5). Priapism occurs in over $40 \%$ of men with SCD, and erectile dysfunction is a consequence of prolonged episodes (6). No standard of care exists for the prophylaxis of recurrent episodes.

Three prior case reports suggested a benefit of HU in the prevention of priapism (7-9). Therefore, we sought to determine the association between HU therapy and the prevention of priapism episodes in men with SCD.

\section{SUBJECTS AND METHODS}

A retrospective case series was conducted between July 1 and September 30, 2014 to evaluate the association between priapism episodes and chronic HU use in men with SCD. The electronic database of the Sickle Cell Unit, The University of the West Indies (UWI), Mona, Jamaica, was searched for all male patients with SCD who had a recorded history of recurrent ischaemic priapism (active or remitted) and also had previous or active treatment with daily HU. All eligible patients were contacted by telephone, and a questionnaire on priapism frequency and duration was completed via an interviewer. The use of named prophylactic agents for priapism was also recorded.

Ethical approval was granted by the University Hospital of the West Indies/The University of the West Indies, Mona, Faculty of Medical Sciences Ethics Committee. Consent was granted by all patients and assent granted by parents of all minors.

The data were analysed with the Stata statistical software for Windows ${ }^{\mathrm{TM}}$ version 12 (College Station, TX 77845, United States of America).

\section{RESULTS}

Of the 15 male patients who fulfilled eligibility criteria, 10 with homozygous SCD of a mean age of $26.2 \pm 10.7$ years consented for the study. The mean age of the onset of HU use was $19.5 \pm 11.04$ years. The most frequent indication for HU use was prevention of recurrent painful crises $(50 \%)$ and stroke $(30 \%)$. The mean duration of HU use was $7.5 \pm 5.1$ years at a mean dose of 19.5 $\pm 7.3 \mathrm{mg} / \mathrm{kg}$. Only two patients had received medical prophylaxis for priapism in the form of hormonal therapy (stilboestrol and pseudoephedrine).

Three patients had frequent priapism episodes, either daily or on alternate days at baseline. The baseline duration of the priapism episodes was over two hours in 50\% of those interviewed, with $30 \%$ lasting over five hours.

One patient interviewed continued to have daily episodes of stuttering priapism while on $\mathrm{HU}$; however, five patients had cessation of episodes while on HU therapy. Of the patients who continued to have priapism while on HU therapy, three had episodes lasting less than 30 minutes, one had episodes of an average duration of one hour, and only one patient continued to have episodes lasting over five hours. 


\section{DISCUSSION}

The results suggested a possible association between chronic HU therapy and reduced frequency and duration of recurrent ischaemic priapism episodes in men with SCD. The mechanism of action of $\mathrm{HU}$ in preventing priapism episodes is presumed to be mediated through its ability to increase bioavailable NO levels. There is a constitutive deficiency of bioavailable NO in SCD. Hydroxyurea contains a NO moiety which is released through unknown mechanisms. Other investigators have revealed that therapy to restore NO homeostasis may reduce priapism in animal models of SCD (10-12). This has translated into clinical effects with chronic therapy with phosphodiesterase inhibitors for SCD-associated priapism prophylaxis (13). An additional effect of $\mathrm{HU}$ which may be beneficial in recurrent ischaemic priapism prophylaxis is its ability to increase $\mathrm{HbF}$ levels which reduces haemolysis (14). This effect potentiates NO homeostasis in SCD. Hydroxyurea may show even greater promise for therapeutics in SCD-mediated priapism by possibly reducing enthothelin-1 mediated corporal fibrosis. Enthothelin-1 levels are elevated in SCD (15), and since it is responsible for fibrosis in several organ systems, it is postulated to be responsible for corporal fibrosis in SCD (9). Anele et al recently reported a case of recovery from erectile dysfunction in a young man with SCD after a prolonged ischaemic priapism episode and administration of chronic HU therapy (9).

Our study represents a small sample cross-sectional study which may be limited by recall bias. The varying natural history of priapism in men with SCD prevents us from reliably attributing the amelioration of priapism episodes completely to the effect of HU. However, we think that the mechanism of action of HU and the demonstrated association of HU therapy with priapism episodes are strong enough to warrant further controlled clinical trials to evaluate prophylactic effects.

\section{REFERENCES}

1. Charache S, Terrin ML, Moore RD, Dover GJ, Barton FB, Eckert SV et al. Effect of hydroxyurea on the frequency of painful crises in sickle cell anemia. Investigators of the multicenter study of hydroxyurea in sickle cell anemia. N Engl J Med 1995; 332: 1317-22.

2. Steinberg MH, Barton F, Castro O, Pegelow CH, Ballas SK, Kutlar A et al. Effect of hydroxyurea on mortality and morbidity in adult sickle cell anemia: risks and benefits up to 9 years of treatment. JAMA 2003; 289: 1645-51.

3. Steinberg MH, McCarthy WF, Castro O, Ballas SK, Armstrong FD, Smith $\mathrm{W}$ et al. The risks and benefits of long-term use of hydroxyurea in sickle cell anemia: a 17.5 year follow-up. Am J Hematol 2010; 85: 403-8.

4. Gladwin MT, Shelhamer JH, Ognibene FP, Pease-Fye ME, Nichols JS, Link B et al. Nitric oxide donor properties of hydroxyurea in patients with sickle cell disease. Br J Haematol 2002; 116: 436-44.

5. Montague DK, Jarow J, Broderick GA, Dmochowski RR, Heaton JP, Lue TF et al. American Urological Association guideline on the management of priapism. J Urol 2003; 170: 1318-24.

6. Pryor J, Akkus E, Alter G, Jordan G, Lebret T, Levine L et al. Priapism J Sex Med 2004; 1: 116-20.

7. Al Jam'a AH, Al Dabbous IA. Hydroxyurea in the treatment of sickle cell associated priapism. J Urol 1998; 159: 1642.

8. Saad ST, Lajolo C, Gilli S, Marques Junior JF, Lima CS, Costa FF et al. Follow-up of sickle cell disease patients with priapism treated by hydroxyurea. Am J Hematol 2004; 77: 45-9.

9. Anele UA, Mack AK, Resar LM, Burnett AL. Hydroxyurea therapy for priapism prevention and erectile function recovery in sickle cell disease: a case report and review of the literature. Int Urol Nephrol 2014; 46: 1733-6.

10. Sopko NA, Matsui H, Hannan JL, Berkowitz D, Champion HC, Hsu LL et al. Subacute hemolysis in sickle cell mice causes priapism secondary to NO imbalance and PDE5 dysregulation. J Sex Med 2015; 12: 1878-85.

11. Musicki B, Bivalacqua TJ, Champion HC, Burnett AL. Sildenafil promotes eNOS activation and inhibits NADPH oxidase in the transgenic sickle cell mouse penis. J Sex Med 2014; 11: 424-30.

12. Bivalacqua TJ, Musicki B, Hsu LL, Berkowitz DE, Champion HC, Burnett AL. Sildenafil citrate-restored eNOS and PDE5 regulation in sickle cell mouse penis prevents priapism via control of oxidative/nitrosative stress. PLoS One 2013; 8: e68028.

13. Burnett AL, Anele UA, Trueheart IN, Strouse JJ, Casella JF. Randomized controlled trial of sildenafil for preventing recurrent ischemic priapism in sickle cell disease. Am J Med 2014; 127: 664-8.

14. Agrawal RK, Patel RK, Shah V, Nainiwal L, Trivedi B. Hydroxyurea in sickle cell disease: drug review. Indian J Hematol Blood Transfus 2014; 30: $91-6$.

15. Hatzipantelis ES, Pana ZD, Gombakis N, Taparkou A, Tzimouli V, Kleta D et al. Endothelial activation and inflammation biomarkers in children and adolescents with sickle cell disease. Int J Hematol 2013; 98: $158-63$. 